\section{The Potential of Strip Tillage and Rowcovers for Organic Cucurbit Production}

\author{
Jason M. Lilley ${ }^{1,3}$ and Elsa S. Sánchez ${ }^{2}$
}

AdDitionAL INDEX WORDs. plasticulture, summer squash, muskmelon, striped cucumber beetle, cover crop

Summary. Plasticulture systems, the use of polyethylene mulch on raised beds with drip irrigation, are commonly used for the production of many cucurbit (Cucurbitaceae) crops. Although the use of plasticulture systems has many benefits, disadvantages include plastic disposal issues and costs and the intensive tillage required for installation. Strip tillage systems have been shown to decrease soil erosion, increase soil moisture retention, and increase soil microbial communities. Spunbonded polyethylene rowcover use has been shown to decrease early season striped cucumber beetle (Acalymma vittatum) and spotted cucumber beetle (Diabrotica undecimpunctata) populations and the incidence of bacterial wilt (Erwinia tracheiphila) while increasing yields. Plasticulture and strip tillage systems were compared with and without rowcovers at The Pennsylvania State University's Russell E. Larson Research and Education Center in Rock Springs, PA. Two separate organically managed experiments were conducted, one being on 'Lioness' summer squash (SS; Cucurbita pepo), the other on 'Athena' muskmelon (MM; Cucumis melo). Both two-season experiments occurred during the 2013 and 2014 growing seasons. Yields, soil nitrate levels, soil and air temperatures, striped cucumber beetle populations, and incidence of bacterial wilt were measured. Plants grown in the strip tillage system generally had lower yields than in the plasticulture system in both years. Yield reductions observed in the strip tillage system in both years of the muskmelon experiment and in the first year of the summer squash experiment were beyond acceptable levels. The need for specialized tillage equipment, delayed planting, and high weed pressure were all obstacles to the successful use of strip tillage in these experiments. Rowcovers resulted in larger plants; however, yields were comparable to not using rowcovers within the strip tillage and plasticulture systems. There was low incidence of bacterial wilt in both years of the experiments despite observed striped cucumber beetle populations above the set threshold throughout all experiments.

$\mathrm{I}$ n the northeastern United States, common production systems for organic vegetable crops, such as MM and SS, often use environmentally costly polyethylene plastic mulches and insecticides that are expensive and only moderately effective (Pedersen and Godfrey, 2011). Research on the feasibility of adopting new ecologically based strategies, such as conservation tillage and the use of rowcovers, will aid growers in keeping up with rising consumer demand for local produce while maintaining or improving the environmental quality of their farms.

Department of Plant Science, 102 Tyson Building, The Pennsylvania State University, University Park, PA 16802

We acknowledge the Specialty Crops Research Initiative for funding this research.

Use of trade names does not imply endorsement of the products named or criticism of similar ones not named.

${ }^{1}$ Graduate Assistant

${ }^{2}$ Associate Professor

${ }^{3}$ Corresponding author. E-mail: jason.lilley@maine. edu.

doi: 10.21273/HORTTECH03405-16
Plasticulture systems, or the use of polyethylene mulch on raised beds with drip irrigation, increase soil temperatures (Yaghi et al., 2013), eliminate the majority of in-row weed competition and result in increased yields compared with bare ground production systems (Berger et al., 2013). Despite these advantages, plastic disposal issues, costs of the materials and labor to install them, and the intensive tillage required for installation, which leads to increased rates of erosion (Hussain and Hamid, 2003; Jabro et al., 2011; Kyrikou and Briassoulis, 2007; Ruidisch et al., 2013) are all disadvantages to this system.

A possible alternative to plasticulture systems are strip tillage systems, which are a form of conservation tillage in which cover crop or previous cash crop residue is left on the soil surface between rows, while a narrow planting row is tilled. Strip tillage that uses cover crops reduces soil erosion (Alliaume et al., 2014; Zhou et al., 2009), increases soil moisture retention (Haramoto and Brainard, 2012), and leads to increased soil microbial populations (Schipanski et al., 2014) with less annual economic input (Archer and Reicosky, 2009) than traditional tillage systems. When compared with bare ground, using strip tillage for horticultural crops has resulted in higher yields of cabbage (Brassica oleracea var. capitata) and cucumber (Cucumis satious) (Haramoto and Brainard, 2012; Wang and Ngouajio, 2008); however, lower yields have been observed with tomato (Solanum lycopersicum) and snapbean (Phaseolus vulgaris) (Alliaume et al., 2014; Bottenberg et al., 1999). It is also noteworthy that none of this research included plasticulture, the standard method of production for many vegetable crops.

Spunbonded polyethylene rowcover installed immediately after planting can suppress some key pest problems of cucurbits. For example, season-long suppression of bacterial wilt on MM, which is vectored by spotted and striped cucumber beetle, was suppressed by the early season use of rowcovers when populations of

\begin{tabular}{llll}
\hline $\begin{array}{l}\text { Units } \\
\begin{array}{l}\text { To convert U.S. to SI, } \\
\text { multiply by }\end{array}\end{array}$ & U.S. unit & SI unit & $\begin{array}{l}\text { To convert SI to U.S., } \\
\text { multiply by }\end{array}$ \\
\hline 0.3048 & $\mathrm{ft}$ & $\mathrm{m}$ & 3.2808 \\
0.0929 & $\mathrm{ft}^{2}$ & $\mathrm{~m}^{2}$ & 10.7639 \\
3.7854 & gal & $\mathrm{L}$ & 0.2642 \\
2.54 & inch(es) & $\mathrm{cm}$ & 0.3937 \\
25.4 & inch $(\mathrm{es})$ & $\mathrm{mm}$ & 0.0394 \\
6.4516 & inch & $\mathrm{cm}^{2}$ & 0.1550 \\
0.4536 & $\mathrm{lb}$ & $\mathrm{kg}$ & 2.2046 \\
1.1209 & $\mathrm{lb} / \mathrm{acre}$ & $\mathrm{kg} \cdot \mathrm{ha}^{-1}$ & 0.8922 \\
0.0254 & $\mathrm{mil}$ & $\mathrm{mm}$ & 39.3701 \\
305.1517 & $\mathrm{oz} / \mathrm{ft}^{2}$ & $\mathrm{~g} \cdot \mathrm{m}^{-2}$ & 0.0033 \\
1 & $\mathrm{ppm}$ & $\mathrm{mg} \cdot \mathrm{kg}^{-1}$ & 1 \\
2.2417 & ton $(\mathrm{s}) / \mathrm{acre}$ & $\mathrm{Mg} \cdot \mathrm{ha}^{-1}$ & 0.4461 \\
$\left({ }^{\circ} \mathrm{F}-32\right) \div 1.8$ & ${ }^{\circ} \mathrm{F}$ & ${ }^{\circ} \mathrm{C}$ & $\left({ }^{\circ} \mathrm{C} \times 1.8\right)+32$
\end{tabular}


these beetles were high (Sánchez et al., 2015). Rowcovers also create beneficial microclimates resulting in increased yields of cucurbits such as butternut squash (Cucurbita moschata) and MM (Sánchez et al., 2015).

In these studies, plasticulture and strip tillage systems were compared with and without rowcovers, in two separate organically managed experiments: one on 'Lioness' SS and the other on 'Athena' MM. Both crops were grown in both seasons.

\section{Materials and methods}

Both experiments were conducted at the Russell E. Larson Research and Education Center, Rock Springs, PA (lat. $40^{\circ} 42^{\prime} 45.04^{\prime \prime} \mathrm{N}$, long. $77^{\circ} 57^{\prime} 12.44^{\prime \prime} \mathrm{W}$ ) with a Hagerstown silty loam soil on a $0 \%$ to $3 \%$ slope. The experimental fields had not been planted in cucurbit crops for at least 2 years before the experiments and were under conventional management. All fields were managed according to the National Organic Program Standards throughout the experiment.

\section{Cover crops}

On 11 Sept. 2012 and 10 Sept. 2013, each experimental field was drilled with nontreated cover crop seed of winter rye (Secale cereale) and hairy vetch (Vicia villosa) (High Mowing Seed Co., Wolcott, VT) at a rate of 67.5 and $22.5 \mathrm{lb} /$ acre, respectively. The field had a history of hairy vetch use and seed was not inoculated with rhizobium. No fertilizers were applied before planting the cover crops and the site only received natural rainfall.

Termination of the rye was accomplished with a single pass with a front-mounted 3-m-wide roller crimper as described by Mischler et al.
(2010) at early anthesis (20 May 2013 and 28 May 2014). The hairy vetch was treated with two passes with the roller crimper when it had developed two pods per vine on 17 June 2013 and 3 July 2014. In 2013 and 2014, 2 and $4 \mathrm{~d}$ after rolling, respectively, the vetch remained alive. On 19 June 2013 and 7 July 2014, a pass with a flail mower set $\approx 12$ inches high ended the hairy vetch.

\section{Definition of treatments}

The whole plot treatments in both years of both experiments consisted of "production system" (plasticulture vs. strip tillage) and the split-plot factor was "rowcover use" (rowcover vs. no-rowcover).

\section{Field preparation}

For the plasticulture plots in both experiments, crop residue was incorporated with two passes of a chisel plow and one pass with a rototiller. A single line of 8 - $\mathrm{mm}$ dripline with 12 -inch emitter spacing and a flow rate of $0.340 \mathrm{gal} / \mathrm{min}$ per 100 $\mathrm{ft}$ (T-Tape ${ }^{\mathrm{TM}}$; John Deere, Moline, IL) was installed over each 2.5 -ftwide and 6-inch-high raised bed covered by 4 -ft-wide 1.25 -mil embossed black polyethylene mulch (Sigma Plastic Groups, Allentown, PA) (Table 1). The beds were spaced $7 \mathrm{ft}$ center-to-center, with four rows per whole plot; two treatment rows flanked by two guard rows.

Strip tillage plots in both experiments were prepared with two passes of a single-row strip tillage implement (6000; Hiniker Co., Mankato, MN) with notched trash cleaning disks, a cutting-coulter, 8-inch-deep shank point assembly, berming disks and rolling basket. Rows were $1 \mathrm{ft}$ wide and spaced $7 \mathrm{ft}$ center-to-center with four rows per whole plot. Cover crop

Table 1. Field preparation practices and dates in 2013 and 2014 for plasticulture (PL) and strip tillage (ST) plots in both the summer squash and muskmelon experiments at Rock Springs, PA.

\begin{tabular}{lll}
\hline Field preparation practice & \multicolumn{1}{c}{$\mathbf{2 0 1 3}$} & \multicolumn{1}{c}{$\mathbf{2 0 1 4}$} \\
\hline $\begin{array}{l}\text { Plant cover crop } \\
\text { Roller crimper for rye termination }\end{array}$ & 11 Sept. (2012) & 10 Sept. (2013) \\
$\begin{array}{l}\text { Mow rye/hairy vetch cover crop } \\
\quad \text { both treatments) }\end{array}$ & 19 June & 28 May \\
Chisel plow, two passes (PL) & 20 June & July \\
Rototill, two passes (PL) & 20 June and 24 June & 3 July \\
Form beds and lay plastic (PL) & 25 June & 7 July \\
ST & 24 June & 8 July \\
\hline
\end{tabular}

residue was left undisturbed between rows. The drip tape described above was also centered over the strip tillage planting rows.

\section{Soil fertility management}

On 13 May 2013 and 27 May 2014, soil samples were taken for analysis of $\mathrm{pH}$, phosphorous, potassium, magnesium, and calcium in each main plot. Cover crop leaf tissue analysis of total nitrogen $(\mathrm{N})$ and biomass was conducted on 16 May 2013 and 27 May 2014 (Sullivan and Andrews, 2012). Soil samples and cover crop leaf tissue analysis were analyzed by the Agricultural Analytical Services Laboratory at The Pennsylvania State University (AASLAB, University Park, PA). Results from both tests were used to determine fertilizer regimes. A total of $75 \mathrm{lb} /$ acre N (Sánchez et al., 2013) was applied preplant for both crops and was supplied both years of both experiments to the strip tillage and plasticulture treatments. Fertility was adjusted for the $\mathrm{N}$ credit from the cover crop, which in 2013 was 33.0 and $34.4 \mathrm{lb} /$ acre plant-available $\mathrm{N}$ in the SS and MM experiments, respectively, and 18.0 and $9.4 \mathrm{lb} /$ acre plantavailable $\mathrm{N}$, respectively, in 2014, calculated via the Sullivan and Andrews technique (2012). The remainder of the nutrient needs was supplied by broadcasting $5 \mathrm{~N}-0.4 \mathrm{P}-$ $0.8 \mathrm{~K}$ granular fertilizer (Blue N; Fertrell Co., Bainbridge, PA) before field preparation.

\section{Soil nitrate levels}

Presidedress nitrate $\left(\mathrm{NO}_{3}-\mathrm{N}\right)$ tests were conducted (AASLAB) in each whole plot in both experiments, 19 and $20 \mathrm{~d}$ after transplanting in 2013 and 2014, respectively (16 July and 30 July). Samples were collected from within the planting row via the Heckman technique (Heckman et al., 2002). A threshold of 25 ppm soil $\mathrm{NO}_{3}-\mathrm{N}$ was used to determine if additional $\mathrm{N}$ needed to be applied. When needed, fish emulsion (5N-0.4P0.8K Aqua Power ${ }^{\mathrm{TM}}$; JH Biotech, Ventura, CA) was applied by fertigation.

\section{Plant selection, seeding, and transplanting}

Nontreated seeds of 'Athena' MM and 'Lioness' SS (Seedway ${ }^{\circledR}$, Mifflinburg, PA) were planted into 48-plug trays in compost and peat-based potting 
soil (512 Organic Mix; Johnny's Selected Seeds, Winslow, ME). Summer squash transplants were seeded on 17 June 2013 and 26 June 2014 and MM were seeded on 11 June 2013 and 24 June 2014 and maintained in greenhouses. Due to forecasted prolonged rain at transplanting time, seedlings were moved directly from the greenhouse to the field in 2013, while in 2014, seedlings were hardened off in a high tunnel for $2 \mathrm{~d}$ before transplanting. Fifteen seedlings were transplanted per subplot with 2 -ft in-row spacing on 26 June 2013 and 10 July 2014 in both experiments.

\section{Rowcovers}

In the SS experiment, 83-inchwide spunbonded polypropylene, 30 -weight $\left(30 \mathrm{~g} \cdot \mathrm{m}^{-2}\right)$ rowcovers (Agribond $^{\mathrm{TM}}$, San Luis Potosi, Mexico) were installed over 64 -inch-long spring steel wire hoops, arched $2 \mathrm{ft}$ high over the rows immediately after transplanting over one row of each main plot. In the MM experiment, 19 weight $\left(19 \mathrm{~g} \cdot \mathrm{m}^{-2}\right)$ rowcovers were installed. One data row and two border rows were left uncovered in each main plot.

Rowcovers were removed from the SS plots when $50 \%$ of the plants under rowcovers in the strip tillage subplots had at least one opened blossom (Hernandez, 2013), on 22 July 2013 and 8 Aug. 2014. This treatment reached this stage later than the other treatments. In hindsight, rowcovers should have been removed as each treatment reached the flowering threshold instead of as a once-over act as will be explained further. Rowcovers were removed from the MM plots $10 \mathrm{~d}$ after the first flower appeared in $50 \%$ of the strip tillage rowcover plots (Hernandez, 2013), on 23 July 2013 and 13 Aug. 2014.

\section{Pest management}

At transplanting, the no-rowcover treatment plots in the SS and MM experiments received a spray application of spinosad (Entrust SC; Dow Agrosciences, Indianapolis, IN) at $0.094 \mathrm{lb} /$ acre mixed with buffalo gourd powder (CideTRAK D; Trécé, Adair, $\mathrm{OK}$ ) at $0.084 \mathrm{lb} /$ acre to manage striped cucumber beetles. The striped cucumber beetle spray threshold was set at one beetle per 10 plants for the first $40 \mathrm{~d}$ after transplanting, then one beetle per plant for the remainder of the season. When the threshold was met, based on weekly scouting events, a tank mixed application of kaolin clay (Surround WP; Novasource, Phoenix, AZ) $30 \mathrm{lb} /$ acre and pyrethrins (Pyganic 5.0; MGK, Minneapolis, MN) at $0.029 \mathrm{lb} / \mathrm{acre}$ was applied. Striped cucumber beetle seasonal dynamics is reported by Lewis (2015).

A 6-inch layer of oat (Avena sativa) straw was applied between rows in the plasticulture plots immediately after transplanting. Hand weeding was used when necessary starting at rowcover removal. Mowing was used for between row weed management in both tillage treatments.

\section{Data collection}

SOIL AND AIR TEMPERATURE. Average air temperatures were recorded daily using a temperature/light data logger $\left(\mathrm{HOBO}^{\circledR}\right.$ Pendant UA-00264; Onset Computer Corp., Bourne, MA) in both experiments during rowcover deployment. Daily average soil temperature was also recorded during rowcover deployment, in the MM experiment only. One pendant per subplot was placed 4 inches below the soil surface for soil temperature and another was placed 16 inches above the soil surface to record air temperature.

Plant size and development. Summer squash plant area $\left(\right.$ inch $^{2}$ ) was measured by multiplying height and width across the row at rowcover removal and again at last harvest.

INCIDENCE OF BACTERIAL WILT. Bacterial wilt was scouted in the SS experiment at midharvest (13 Aug. 2013 and I Sept. 2014) and at final harvest (2 Sept. 2013 and 15 Sept. 2015). Scouting in the MM experiment occurred at first harvest ( 5 Sept. 2013 and 22 Sept. 2014) and again at last harvest in 2013 (27 Sept.) and midharvest in 2014 (6 Oct.) to collect data before vine killing frost occurred. Plants expressing symptoms, including wilted leaves, interveinal chlorosis, or necrosis, were flagged. If symptoms worsened 1 week later and bacterial streaming was observed, they were marked as diseased with bacterial wilt.

YIELDS. Summer squash harvests occurred three times per week from 24 July 2013 to 2 Sept. 2013 and 8 Aug. 2014 to 15 Sept. 2014. The number and weight of marketable fruit (blemish free, between 6 and 10 inches long) and unmarketable fruit (greater than 10 inches, insect damaged, diseased, or physically damaged) from all 15 plants per plot were recorded. Muskmelon harvests occurred twice per week from 5 Sept. 2013 to 27 Sept. 2013 and 22 Sept. 2014 to 20 Oct. 2014. The end of the harvest was determined when all melons were harvested or vine killing frost was experienced. All ripe fruit were harvested. Blemish free melons $3 \mathrm{lb}$ or heavier were categorized as marketable. Unmarketable fruit categories included small (under $3 \mathrm{lb}$ ), discolored, insect damaged, rodent or bird damaged, and diseased. Reason for unmarketability was recorded in both experiments.

STATISTICAL DESIGN AND ANALYSIS. For both experiments and years, a split-plot factorial design was used, with production system (strip tillage, plasticulture) being the whole plot treatment and rowcover use (rowcover, no-rowcover) being the subplot treatment. Each treatment was replicated four times. The 2013 and 2014 data were analyzed separately with SAS (version 9.4; SAS Institute, Cary, NC). Yields, mean air and soil temperature, plant size, and striped cucumber beetle populations were analyzed using PROC MIXED. Production system and rowcover use were analyzed as fixed effects while blocking was analyzed as a random effect. Soil $\mathrm{NO}_{3}-\mathrm{N}$ levels were analyzed with a two sample $t$ test using Minitab $^{\circledR}$ 17.1.0 (Minitab, State College, PA) after ensuring normality. No transformations were necessary.

\section{Results and discussion}

Soil Nitrate Levels. Most vegetable crops require $20-30$ ppm soil $\mathrm{NO}_{3}-\mathrm{N}$ when rapid plant growth begins (about 2 weeks after transplanting for cucurbits) for adequate vegetative growth and productivity throughout the season (Hartz et al., 2000; Heckman et al., 2002). Despite preplant application of the full $\mathrm{N}$ recommendation in both experiments in both years, the 2013 soil $\mathrm{NO}_{3}-\mathrm{N}$ concentration was below 11 $\mathrm{ppm}$ in the plasticulture and strip tillage treatments in both experiments. In that season, 4.13 and 4.29 tons/acre of cover crop dry material were present in the SS and MM fields, 
respectively. The high amount of biomass in the field may have resulted in immobilization of $\mathrm{N}$. As a result of the low early season soil $\mathrm{NO}_{3}-\mathrm{N}$ concentrations, $2.4 \mathrm{lb} /$ acre $\mathrm{N}$ was applied weekly for 6 weeks in 2013, with an Organic Material Review Instituteapproved fish emulsion $(5 \mathrm{~N}-0.4 \mathrm{P}-0.8 \mathrm{~K}$ Aqua Power $\left.{ }^{\mathrm{TM}}\right)$. In 2014, soil $\mathrm{NO}_{3}-\mathrm{N}$ concentrations in plasticulture plots of the SS and MM experiments were 44.52 and 34.88 ppm $\mathrm{NO}_{3}-\mathrm{N}$, respectively, and were over seven times the levels observed in the SS and MM strip tillage plots (4.89 and 5.67 ppm $\mathrm{NO}_{3}-\mathrm{N}$, respectively). Concentrations were sufficient in the plasticulture plots, but an additional $40 \mathrm{lb} /$ acre $\mathrm{N}$ as a pelletized chicken manure (Fertrell $^{\circledR} 5 \mathrm{~N}-0.4 \mathrm{P}-0.8 \mathrm{~K}$ Blue $\mathrm{N}$ ) was side dressed on 4 Aug. 2014 in the strip tillage plots in both experiments. As a result of the cool spring in 2014, the cover crop biomass in that season was 1.4 and 1.34 tons/acre dry weight in the SS and MM experiments, respectively, being significantly lower than in 2013.

Although initial fertilizer rate, source and application method, cover crop biomass, and termination practices were the same in both production system treatments, other factors that influence $\mathrm{N}$ availability in the soil were different between the two, including fertilizer incorporation (Chen et al., 2014), management of the cover crop residue or tillage (Yaffa et al., 2000), soil temperature, and soil moisture (Lawson et al., 2013). Incorporation of the cover crop residue in the plasticulture treatment may have resulted in increased moisture surrounding the residue and greater surface area of the residue exposed to soil microbes than the residue that was left on the soil surface. Cover crop residue on the soil surface in the strip tillage treatment was exposed to higher temperature, sunlight, and wind than the incorporated residue. This interception of sunlight by the cover crop residue, as opposed to the soil surface, likely discouraged microbial activity on the cover crop residue and cooled the soil. Lawson et al. (2013) reported that $68-86^{\circ} \mathrm{F}$ is the ideal soil temperature for mineralization of organic $\mathrm{N}$ sources. Soil temperatures observed in our MM experiment were on average $4^{\circ} \mathrm{F}$ warmer in plasticulture than strip tillage plots (Fig. 2), resulting in soil temperatures in the plasticulture plots ranging from the mid to upper range of the optimal mineralization temperatures, whereas the strip tillage soil temperatures were in the low-to-mid range.

When plastic mulch is added to a system, as compared with bare soil, soil $\mathrm{N}$ mineralization and movement is altered. Plastic mulches exclude excessive water from heavy rainfall events from the root zone, in turn reducing $\mathrm{N}$ leaching from the system (Zotarelli et al., 2008). Berger et al. (2013) observed that the use of plastic mulch on ridges can reduce volatilization of $\mathrm{N}_{2} \mathrm{O}$ from the planting zone, compared with ridges without plastic mulch, increasing the $\mathrm{N}$ that remains in the systems to be used by the crop, or subsequent crops. This reduction of $\mathrm{N}$ loss due to plastic mulch may have contributed to the higher or equal $\mathrm{NO}_{3}-\mathrm{N}$ levels in the plasticulture plots as compared with the strip tillage plots.

Chen et al. (2014) reported a $68 \%$ reduction in ammonia emissions when manure was injected into the soil vs. being broadcasted on the soil surface. The preplant-broadcasted granular organic fertilizer in both treatments of these experiments was incorporated into the soil in the plasticulture plots while being incorporated only in the planting row of the strip tillage plots and left on the surface between rows, leading to possible ammonia volatilization.

WEED DENSITY. Weed control was the main contributor to midseason labor requirements in the strip tillage system. To maintain insect pest exclusion, the rowcover was left on until the timing of removal described in the methods section. As a result, weeds were not managed in either the rowcover or no-rowcover plots until that time. Although significantly higher weed densities were observed in the strip tillage compared with plasticulture treatments, no differences between rowcover treatments in either year of either experiment were observed. The broad leaves and upright, bush type growth habit of SS plants reduced season-long in-row weed pressure by effectively shading the soil and slowing the growth of emerging weed seedlings.

In the SS experiment, the average in-row weed density of both rowcover treatments at rowcover removal in the strip tillage treatment was
282.0 and $204.1 \mathrm{lb} /$ acre in 2013 and 2014 , respectively. The low vining growth habit of the MM made weed management challenging, resulting in an average weed biomass of 382.4 and $1062.3 \mathrm{lb} /$ acre in 2013 and 2014 , respectively. As a result of the higher weed densities in the MM experiment, two hand weeding events occurred in both seasons, although one hand weeding per season was sufficient in the SS experiment. In both years of both experiments, weed populations were primarily annual broadleaf species including pigweed (Amaranthussp.), common purslane (Portulaca oleracea), shepherd'spurse (Capsella bursa-pastoris), common lambsquaters (Chenopodium album), and pennsylvania smartweed (Polygonum pensylvanicum). Plasticulture plots had very little in-row weed pressure in both years of both experiments. Tillman et al. (2015) also noted difficulty in managing weeds as a result of rowcover use as well as similarly high weed pressure in strip tillage systems compared with plasticulture with MM crops.

INSECT PEST AND DISEASE PRESSURE AND PESTICIDE APPLICATIONS. In both production systems and experiments, at least one insecticide spray event was avoided with the use of rowcover. In 2013 , in the SS experiment, the spray threshold for striped cucumber beetles was passed once after rowcover removal in the strip tillage treatment and twice in the plasticulture treatment (Fig. 1). In the 2014 season, striped cucumber beetle populations in the SS plasticulture treatment were over threshold three consecutive weeks before rowcover removal (Lewis, 2015) (Fig. 2), resulting in the elimination of three insecticide applications compared with the plasticulture no-rowcover treatment and two fewer applications in the strip tillage rowcover treatment compared with strip tillage no-rowcover.

Only one SS plant was observed with bacterial wilt out of all data plots in 2013, whereas in 2014, a slightly higher incidence of infected plants at the end of the season was observed with the only significant difference being between the plasticulture no-rowcover treatment (30.0\% of plants infected) compared with strip tillage no-rowcover $(6.7 \%$ of plants infected $)(P=0.016)$.

In 2013, in the MM experiment, one insecticide application for striped 
cucumber beetles was avoided (during the week of 31 July) within both production systems by the use of rowcovers (Fig. 3). Striped cucumber beetle pressure was much higher in 2014 resulting in seven insecticide applications in the plasticulture norowcover treatment and six applications in the plasticulture rowcover treatment (Fig. 4). Strip tillage norowcover treatments typically had the lowest striped cucumber beetle populations likely because plants in those plots were less developed and had less foliage for insects to feed on (data not shown). Despite nearly weekly insecticide applications in 2014, striped cucumber beetle populations remained above thresholds throughout the season.

Bachmann (2012) projects the emergence of the first field generation of striped cucumber beetle adults in Pennsylvania to be 794 degree-days at base $55{ }^{\circ} \mathrm{F}(\mathrm{DD})$ after overwintered adults become active. Bachmann assumed that overwintered adult striped cucumber beetles became active at 250 DD after l Jan. This would predict that the first field generation of striped cucumber beetle adults in this research would emerge on 20 July 2013 and 2 Aug. 2014. This is 24 and $23 \mathrm{~d}$ after transplanting in 2013 and 2014, respectively, about 2 weeks before rowcover removal. Our research observed increases in striped cucumber beetle populations that match the predicted dates of emergence of the first field generation (Figs. 1-4), leading to the conclusion that the Bachmann (2012) striped cucumber beetle phenology data are a useful management tool for making decisions based on striped cucumber beetle emergence timing. For example, if higher early season striped $\mathrm{cu}^{-}$ cumber beetle pressure is experienced, as in this research in 2014, fewer insecticide applications are needed as a result of rowcover use.

Corresponding with low-striped cucumber beetle pressure in the 2013 MM crop, there were very few observed incidences of bacterial wilt that year. Despite increased striped cucumber beetle pressure in 2014, low incidence of the infected plants was observed again with an average of $8.33 \%$ infected in plasticulture norowcover treatment as compared with only $1.67 \%$ in the plasticulture rowcover treatment $[P=0.05$ (data not shown)]. No bacterial wilt was detected in strip tillage plots.

Striped cucumber beetles, vectors of bacterial wilt, are the primary insect pest of cucurbits in the northeast (Cavanagh et al., 2009). The increased insect pest pressure in 2014 was anticipated to result in higher amounts of infection. Although more incidence of the disease was detected in 2014 than 2013 , the rate of infection was still relatively low, not appearing to have any significant impact on yields. As anticipated, slightly higher rates of the infected plants were detected in the no-rowcover plots. Hernandez (2013), Rojas et al. (2011), and Sánchez et al. (2015) demonstrated that rowcover use reduces the seasonlong incidence of bacterial wilt in years with high beetle pressure.

SS PLANT SIZE AT ROWCOVER REMOVAL. Interactions were observed between SS production system and rowcover use for plant size at rowcover removal. In 2013, the plasticulture with rowcover treatment resulted in smaller plants than the no-rowcover treatment early and late in the season; however, rowcover use in the strip tillage treatment resulted in larger plants at rowcover removal than in the no-rowcover treatment of that production system (Table 2). In 2014, equal plant sizes were observed in all treatments except the strip tillage no-rowcover treatment, in which plants were smaller.

SuMMER SQUASH YIELDS. Interactions were observed between production system and rowcover treatment in total (marketable and unmarketable combined) and marketable yields in both seasons. In 2013, total and marketable fruit weight from the plasticulture with rowcover treatment was lower than from the no-rowcover plasticulture plots. Higher total fruit weight was observed with rowcover use in the strip tillage treatment as compared with the no-rowcover treatment in both years. In 2014, no difference in marketable and total yields within the plasticulture treatment with and without the use of rowcover was observed (Table 3 ).

In 2013, marketable fruit weight from strip tillage plots was $49.7 \%$ lower than from plasticulture plots $(P=0.001)$. The lower yields were observed in both rowcover and no-rowcover strip tillage treatments.

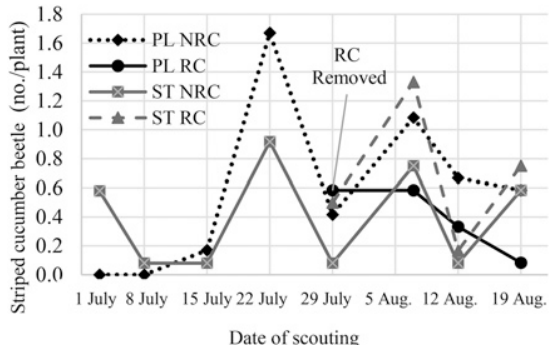

Fig. 1. Striped cucumber beetle (SCB) seasonal population dynamics in plasticulture (PL) and strip tillage (ST) production systems with (RC) or without (NRC) the use of rowcover in a summer squash experiment in Pennsylvania in 2013. Each value is the number of SCB per plant during weekly scouting events, beginning 1 week after transplanting and ending 1 week before the final harvest.

Striped cucumber beetle populations in rowcover plots before rowcovers were removed ( $\mathrm{RC}$ removed) were not included as SCB were excluded from the plant zone by the rowcovers.

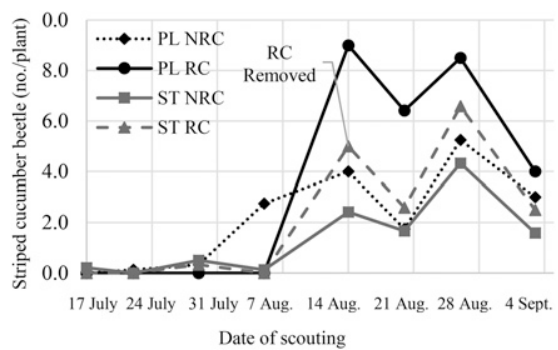

Fig. 2. Striped cucumber beetle (SCB) seasonal population dynamics in plasticulture (PL) and strip tillage (ST) production systems with (RC) or without (NRC) the use of rowcover in a summer squash experiment in Pennsylvania in 2014. Each value is the number of SCB per plant during weekly scouting events, beginning 1 week after transplanting and ending 1 week before the final harvest.

Striped cucumber beetle populations in rowcover plots before rowcovers were removed ( $\mathrm{RC}$ removed) were not included as SCB were excluded from the plant zone by the rowcovers.

Similar differences in marketable yields were observed in the 2014 no- $^{-}$ rowcover strip tillage treatment, with yields being $54.9 \%$ lower than yields from the plasticulture plots without rowcovers $(P=0.015)$, yet no differences were observed between plasticulture and strip tillage with rowcover treatments $(P=0.829)$.

In 2013, unmarketable yields accounted for $25 \%$ of the total fruit 


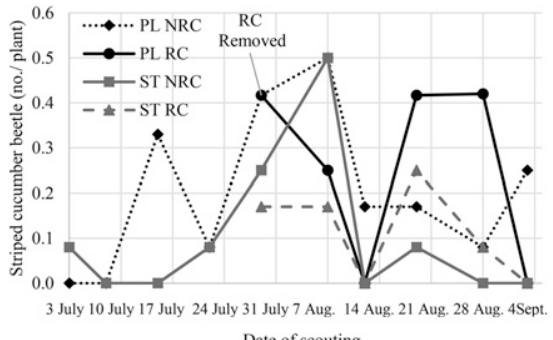

Date of scouting

Fig. 3. Striped cucumber beetle (SCB) seasonal population dynamics in plasticulture $(P L)$ and strip tillage (ST) production systems with (RC) or without (NRC) the use of rowcover in a muskmelon experiment in Pennsylvania in 2013. Each value is the number of SCB per plant during weekly scouting events, beginning 1 week after transplanting and ending 2 weeks before the final harvest. Striped cucumber beetle populations in rowcover plots before rowcovers were removed ( $\mathrm{RC}$ removed) were not included as SCB were excluded from the plant zone by the rowcovers.

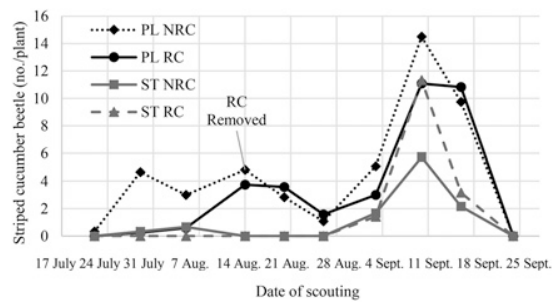

Fig. 4. Striped cucumber beetle (SCB) seasonal population dynamics in plasticulture (PL) and strip tillage (ST) production systems with (RC) or without (NRC) the use of rowcover in a muskmelon experiment in Pennsylvania in 2014. Each value is the number of SCB per plant during weekly scouting events, beginning 1 week after transplanting and ending 2 weeks before the final harvest. Striped cucumber beetle populations in rowcover plots before rowcovers were removed ( $\mathrm{RC}$ removed) were not included as SCB were excluded from the plant zone by the rowcovers.

weight in rowcover treatments and $17.5 \%$ of no-rowcover treatments. Rowcover use resulted in higher unmarketable yields in the strip tillage treatment, but not in the plasticulture treatment. In 2014, the percentage of the total yields categorized as unmarketable was different between production systems with the plasticulture treatments $(28 \%)$ being nearly double that of the strip tillage treatments
(15\%). Unmarketability in both seasons was primarily due to over-sized fruit.

In the SS experiment in 2013, the extensive mechanical damage to the plants in the plasticulture with rowcover treatment caused by late timing of rowcover removal resulted in reduced yields and resulted in higher yields in the plasticulture norowcover treatment. In 2014, SS yields showed fewer disparities between treatments, with only yield from the strip tillage no-rowcover treatment being lower than the others. Strip tillage with rowcover in 2014 yielded equally to both plasticulture treatments. The larger plants at rowcover removal and $45 \%$ higher yields in strip tillage with rowcover compared with no-rowcover demonstrates that rowcovers have the potential to increase plant growth and yields given appropriate conditions and timing of rowcover removal.

MM YIELDS. No interactions of total, marketable, or unmarketable yields were observed between production system and rowcover treatment. In 2014, marketable yields from plasticulture plots were $55 \%$ lower and from strip tillage plots $20 \%$ lower than in 2013 (Table 3). Rowcover use within production system had no effect on total and marketable yields for all treatments except the 2013 marketable yields in the plasticulture treatments, where rowcovers increased fruit weight $(P=$ $0.05)$. Regardless of rowcover treatment, differences were observed between production systems with the strip tillage marketable fruit weight being 63\% (2013) and 93\% (2014) lower than plasticulture yields. In 2014, marketable yields were $86 \%$ lower in the strip tillage with rowcover treatment compared with the plasticulture with rowcover treatment. The rowcover treatment was the most productive treatment within both production systems. The late maturation, and therefore termination, of the cover crop in 2014 led to a very late planting date in that season. As a result, MM did not have time to mature before the cool fall temperatures began, resulting in many fruit never reaching maturity.

Unmarketable yields were equally very low in all treatments in 2013 , being less than $2.4 \%$ of total fruit weight. In 2014, plasticulture unmarketable yields were $9 \%$ and $12 \%$ of the total fruit weight with and without rowcover, respectively. In that season, the unmarketable plasticulture yields were not different from the marketable strip tillage yields. Yields of both crops were expected to be highest in the plasticulture production system and in the rowcover plots.

SoIl Temperature. No interactions were observed between tillage treatments and rowcover use. Average soil temperatures in the MM experiment throughout rowcover deployment were an average of 5.5 and $4{ }^{\circ} \mathrm{F}$ warmer in the plasticulture plots than strip tillage plots in 2013 and 2014, respectively (Fig. 5 ).

Higher soil temperatures in the plasticulture treatment compared with the strip tillage treatment not only likely increased the mineralization rate of organic $\mathrm{N}$ but also correlated strongly to MM yields. Ibarra et al. (2001) showed a strong relationship of MM plant biomass and yields to accumulation of degree-days measured as soil temperature. This correlation was stronger with soil temperatures than with air temperature. Ruiz-Machuca et al. (2015) showed strong relationships between soil temperature and potato plant growth $\left(R^{2}=0.94\right)$ and between potato plant biomass and yields $\left(R^{2}=\right.$ 0.98). This research also showed strong relationships between soil temperatures and marketable yields $\left(2013, R^{2}=0.762 ; 2014, R^{2}=0.914\right)$ (Fig. 6).

Air temperature. Season-long, daily average temperatures in the plant canopy zone in both experiments were consistently higher in the rowcover treatments (Fig. 5). No interactions were observed in either experiment between production system and rowcover use during rowcover deployment in either growing season. Throughout rowcover deployment in the SS experiment in 2013, the season-long average air temperatures with rowcover, regardless of production system, were $3{ }^{\circ} \mathrm{F}$ higher than in no-rowcover plots $(P=$ 0.002 ). In 2014, average air temperatures in SS rowcover plots were as high as $9{ }^{\circ} \mathrm{F}$, higher than with norowcover $3 \mathrm{~d}$ after deployment, all of which were in the first half of the rowcover deployment period. Air temperatures below rowcovers in the 
Table 2. Summer squash plant size at rowcover removal (early season) and at last harvest (late season) by production system and rowcover treatment in 2013 and 2014 at Rock Springs, PA.

\begin{tabular}{llcccc}
\hline $\begin{array}{l}\text { Production } \\
\text { system }\end{array}$ & $\begin{array}{l}\text { Rowcover } \\
\text { treatment }\end{array}$ & Early season (2013) & Late season (2013) & Early season (2014) & Late season (2014) \\
\cline { 3 - 6 } Plasticulture & Rowcover & $831 \mathrm{c}^{\mathrm{y}}$ & $1,686 \mathrm{~b}$ & $1,106 \mathrm{a}$ & $1,892 \mathrm{a}$ \\
& No-rowcover & $1,269 \mathrm{a}$ & $2,234 \mathrm{a}$ & $1,200 \mathrm{a}$ & $1,879 \mathrm{a}$ \\
Strip tillage & Rowcover & $1,020 \mathrm{~b}$ & $1,514 \mathrm{bc}$ & $1,117 \mathrm{a}$ & $1,671 \mathrm{a}$ \\
& No-rowcover & $609 \mathrm{~d}$ & $1,309 \mathrm{c}$ & $358 \mathrm{~b}$ & $1,341 \mathrm{~b}$ \\
\hline
\end{tabular}

${ }^{2}$ Measurement of the plant canopy across rows by the plant height; 1 inch ${ }^{2}=6.4516 \mathrm{~cm}^{2}$.

Values within the same column followed by different letters differ at $P<0.05$. Using the SLICE statement [PROC MIXED of SAS (version 9.4; SAS Institute, Cary, NC)], LS means for each production system were compared within each level of rowcover.

Table 3. Marketable and unmarketable summer squash and muskmelon yield per 15 plants [i.e., $30 \mathrm{ft}(9.14 \mathrm{~m})$ of row, one $210 \mathrm{ft}^{2}\left(19.5 \mathrm{~m}^{2}\right)$ plot] by production system and rowcover treatment in 2013 and 2014 at Rock Springs, PA.

\begin{tabular}{|c|c|c|c|c|c|c|}
\hline \multirow[b]{3}{*}{ Expt. } & \multicolumn{2}{|c|}{ Treatment } & \multicolumn{2}{|c|}{2013} & \multicolumn{2}{|c|}{2014} \\
\hline & \multirow{2}{*}{$\begin{array}{c}\text { Production } \\
\text { system }\end{array}$} & \multirow{2}{*}{$\begin{array}{l}\text { Rowcover } \\
\text { treatment }\end{array}$} & Marketable & Unmarketable & Marketable & Unmarketable \\
\hline & & & \multicolumn{4}{|c|}{ Yield (lb/15 plants) ${ }^{\mathrm{z}}$} \\
\hline & & No-rowcover & $93.5 \mathrm{a}$ & $23.5 \mathrm{a}$ & $78.7 \mathrm{a}$ & $35.0 \mathrm{a}$ \\
\hline & Strip tillage & Rowcover & $48.2 \mathrm{c}$ & $15.5 \mathrm{~b}$ & $77.9 \mathrm{a}$ & $13.8 \mathrm{~b}$ \\
\hline & & No-rowcover & $36.7 \mathrm{~d}$ & $7.0 \mathrm{c}$ & $43.2 \mathrm{~b}$ & $7.8 \mathrm{c}$ \\
\hline & Strip tillage & Rowcover & $60.9 \mathrm{c}$ & $0.8 \mathrm{a}$ & $12.5 \mathrm{~b}$ & $3.9 \mathrm{~b}$ \\
\hline & & No-rowcover & $58.1 \mathrm{c}$ & $1.0 \mathrm{a}$ & $0.0 \mathrm{~b}$ & $0.3 \mathrm{~b}$ \\
\hline
\end{tabular}

${ }^{\mathrm{z}} \mathrm{l} \mathrm{lb} / 15$ plants $=207.4286 \mathrm{lb} /$ acre $=232.4965 \mathrm{~kg} \cdot \mathrm{ha}^{-1}$.

Values are the mean of four replications; values within the same column followed by different letters differ at $P<0.05$. Using the SLICE statement [PROC MIXED of SAS (version 9.4; SAS Institute, Cary, NC) ], LS means for each production system were compared within each level of rowcover.
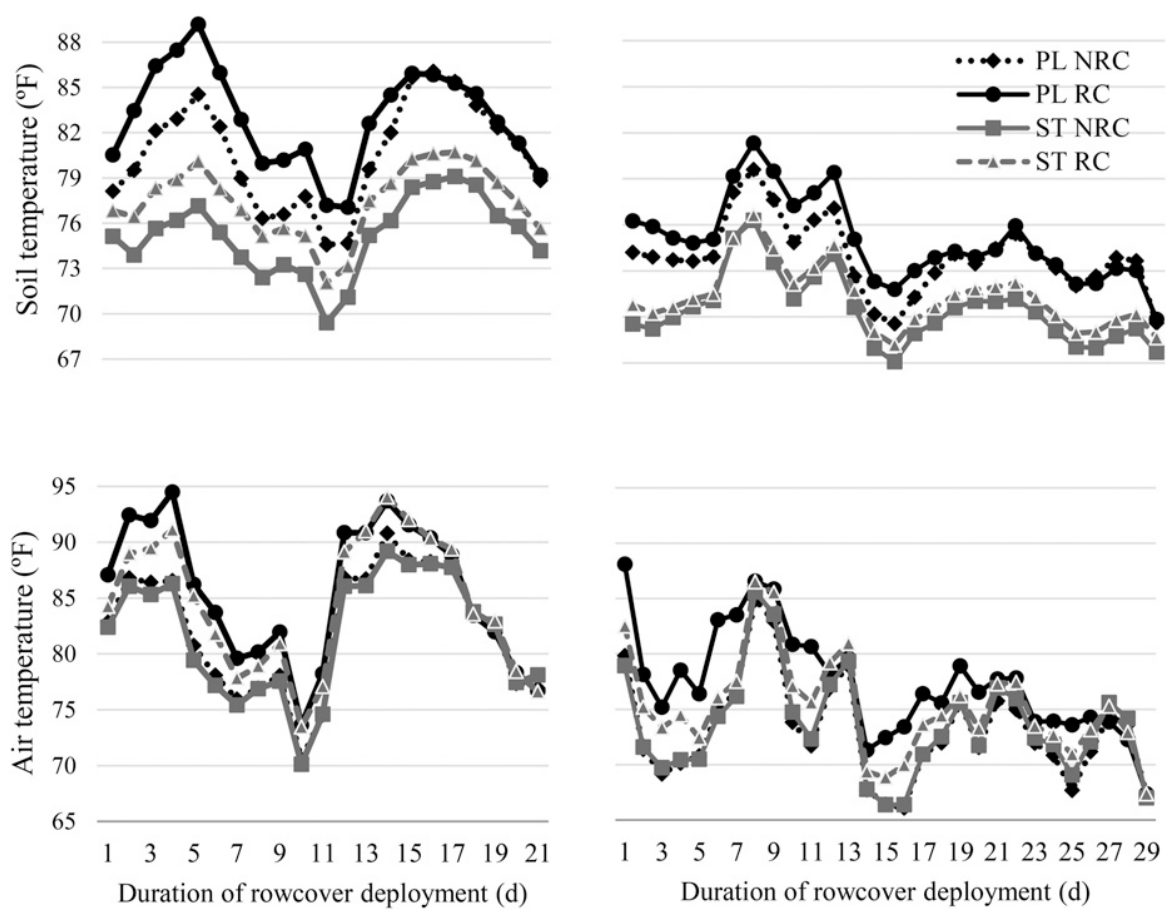

Fig. 5. Daily average soil and air temperatures in 2013 and 2014 in a muskmelon experiment in plasticulture $(\mathrm{PL})$ and strip tillage $(\mathrm{ST})$ production with $(\mathrm{RC})$ or without (NRC) the use of rowcovers. Rowcovers were installed at planting and removed when the first flower appeared in half of the experimental plots. Deployment occurred from 3 to 24 July 2013 and 16 July to 12 Aug. 2014; $\left({ }^{\circ} \mathrm{F}-32\right) \div 1.8={ }^{\circ} \mathrm{C}$.
MM experiment were an average of $5.3{ }^{\circ} \mathrm{F}$ higher than in no-rowcover plots while rowcovers were deployed, regardless of production system treatment $(P<0.001)$. Season average air temperatures between production systems were not statistically different in all comparisons for both experiments.

The increase in air temperature as a result of rowcover use appeared to be associated with increased plant size. Maximum daily air temperatures were as much as $14{ }^{\circ} \mathrm{F}$ higher in plasticulture with rowcover than norowcover treatments in the $2013 \mathrm{MM}$ experiment, resulting in temperatures as high as $120{ }^{\circ} \mathrm{F}$. These extreme temperatures were anticipated to have detrimental effects on the plants, yet visual inspection throughout the rowcover deployment period indicated larger plant size as a result of rowcover use. The smaller plant size observed in the 2013 plasticulture with rowcover treatments in the SS experiment was a result of mechanical damage due to direct constriction of the plants under the rowcover, as opposed to physiological damage due to heat stress. The damage caused 
A

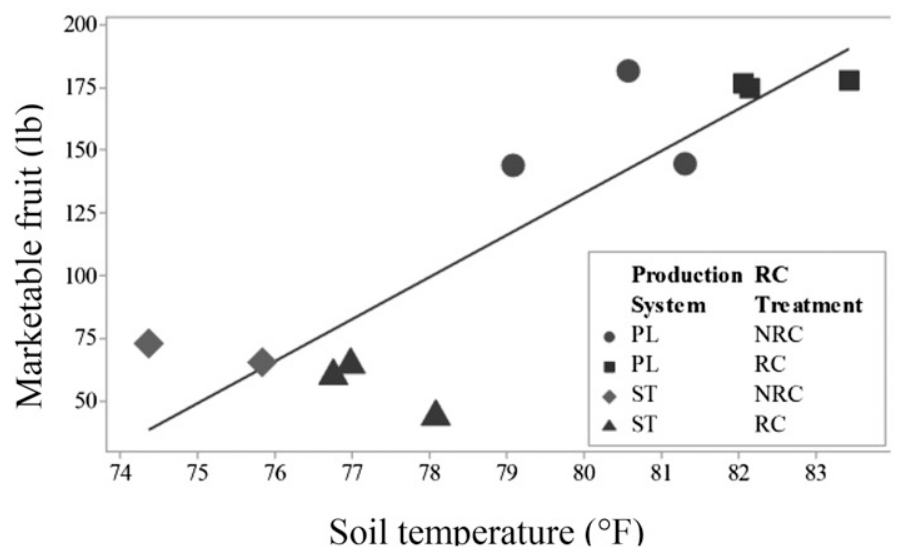

B

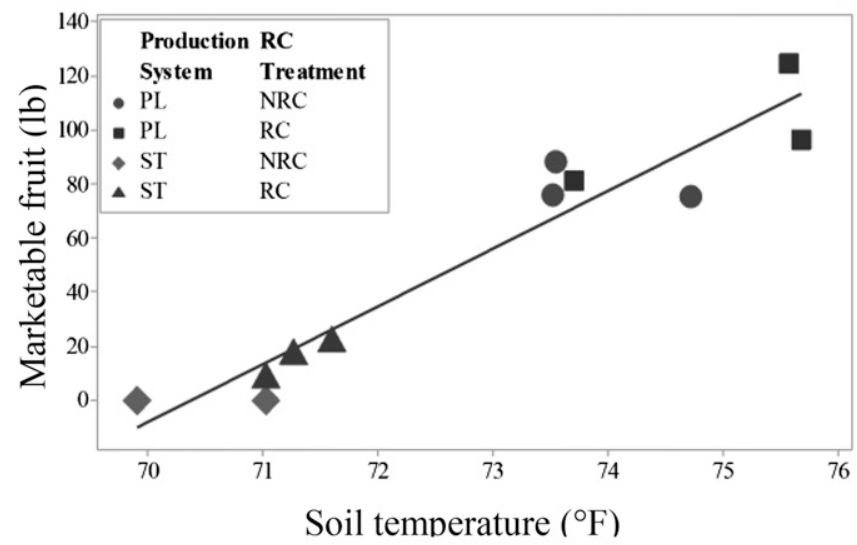

Fig. 6. Season total marketable weight of muskmelon fruit produced in 2013 (A) and 2014 (B) regressed with average soil temperature during rowcover deployment. Plants were produced in plasticulture (PL) or strip tillage (ST) systems with (RC) or without (NRC) the use of rowcovers. Rowcovers were installed at planting and removed when the first flower appeared in half of the experimental plots; 2013 yields $=-1206+16.73$ soil temperature, $R^{2}=0.762 ; 2014$ yields $=-1511+21.46$ soil temperature, $R^{2}=0.914 ;\left({ }^{\circ} \mathrm{F}-32\right) \div 1.8={ }^{\circ} \mathrm{C}, 1 \mathrm{lb}=0.4536 \mathrm{~kg}$.

to these plants was a result of, and in fact more severe with increased growth, and could have been avoided with an earlier removal of the rowcover. The elevated air temperatures and decreased light levels (data not shown) under the rowcover are attributed to increased yields in rowcover plots. Soltani et al. (1995) reported that light levels under rowcover still exceed light saturation levels of watermelon and in fact reduce plant stress, possibly enhancing growth. Higher yields in plasticulture plots may be attributed to increased soil temperatures, which affect plant nutrient uptake, and also the further elevated air temperatures under rowcovers, and decreased weed pressure (Ibarra-Jimenez et al., 2006).

\section{Conclusion}

This research demonstrated the difficulties of using a strip tillage production system for organic cucurbit production. Equal or lower early season soil $\mathrm{NO}_{3}-\mathrm{N}$ levels were observed in strip tillage plots as compared with plasticulture. The use of black plastic mulch led to increased soil temperatures in the plasticulture treatments as compared with the strip tillage treatment where plant residue on the soil surface likely led to cooler soil temperatures. This increase in soil temperature in the plasticulture treatment was highly correlated to higher yields of both cucurbit crops and may have also resulted in increased $\mathrm{N}$ mineralization. Additionally, the plastic mulch decreased weeds compared with the strip tillage system. The rowcovers resulted in increased air temperatures around the plants during deployment and excluded striped cucumber beetles. Despite these advantages to using black plastic mulches, the installation and disposal of the plastic mulches have large environmental impacts. The use of strip tillage showed dramatically lower MM yields, showing their incompatibility with this system, while equal to significantly lower SS yields were observed. Drastically reduced yields of both crops were also observed in similar research conducted at other universities (Ohio State University, University of Kentucky, and Iowa State University) leading to the conclusion that strip tillage was not a suitable alternative to a plasticulture production system for the production of SS or MM under these conditions (Tillman et al., 2015; M.E. Dieterich and A. Skidmore, personal communication).

The use of rowcovers is a significant on-farm investment, yet may be the only effective organically approved management strategy against economically important pests of $\mathrm{cu}^{-}$ curbits. Aside from the cost of the material and installation, and the difficulty of weeding during rowcover deployment, benefits observed from the use of rowcovers include significantly increased air temperatures, resulting in larger MM and SS plants. If mechanical damage is avoided, rowcovers increased crop yields in many cases, especially SS yields. Other benefits of rowcovers included reducing as many as three applications of costly organic insecticides and a slight reduction in incidence of bacterial wilt.

\section{Literature cited}

Alliaume, F., W.A.H. Rossing, P. Tittonell, G. Jorge, and S. Dogliotti. 2014. Reduced tillage and cover crops improve water capture and reduce erosion of fine textured soils in raised bed tomato systems. Agr. Ecosyst. Environ. 183:127-137.

Archer, D.W. and D.C. Reicosky. 2009. Economic performance of alternative tillage systems in the northern corn belt. Agron. J. 101:296-304.

Bachmann, A. 2012. Using population structure and phenology to advance insect management in diversified agroecosystems. PhD Diss., Pennsylvania State Univ., University Park.

Berger, S., Y. Kim, J. Kettering, and G. Gebauer. 2013. Plastic mulching in agriculture: Friend or foe of $\mathrm{N}_{2} \mathrm{O}$ emissions? Agr. Ecosyst. Environ. 167:43-51.

Bottenberg, H., J. Masiunas, and C. Eastman. 1999. Strip tillage reduces yield loss of snapbean planted in rye mulch. HortTechnology 9:235-240.

Cavanagh, A., R. Hazzard, L.S. Adler, and J. Boucher. 2009. Using trap crops for control of Acalymma vittatum (Coleoptera: Chrysomelidae) reduces insecticide use in butternut squash. J. Econ. Entomol. 102:1101-1107.

Chen, L., C.W. Gray, H. Neibling, S.K.R. Yadanaparthi, M. Chahine, and M.E.D. 
Marti. 2014. On-farm comparison of two dairy manure application methods in terms of ammonia and odor emissions and costs. Appl. Eng. Agr. 30:805-813.

Haramoto, E.R. and D.C. Brainard. 2012. Strip tillage and oat cover crops increase soil moisture and influence $\mathrm{N}$ mineralization patterns in cabbage. HortScience 47:1596-1602.

Hartz, T.K., W.E. Bendixen, and L. Wierdsma. 2000. The value of presidedress soil nitrate testing as a nitrogen management tool in irrigated vegetable production. HortScience 35:651-656.

Heckman, J.R., T. Morris, J.T. Sims, J.B. Sieczka, U. Krogmann, P. Nitzsche, and R. Ashley. 2002. Pre-sidedress soil nitrate test is effective for fall cabbage. HortScience 37:113-117.

Hernandez, E.H. 2013. Integrating rowcovers, compost and rhizobacteria to manage nutrients and key pests in organic cucurbit production. PhD Diss., Pennsylvania State Univ., University Park.

Hussain, I. and H. Hamid. 2003. Plastics in agriculture, p. 185-209. In: A.L. Andrady (ed.). Plastics and the environment. Wiley, Hoboken, NJ.

Ibarra, L., J. Flores, and J.C. Diaz-Perez. 2001. Growth and yield of muskmelon in response to plastic mulch and rowcovers. Sci. Hort. 87:139-145.

Ibarra-Jimenez, L., R. Quezada-Martin, B. Cedeno-Rubalcava, A.J.D. Rio, and M. de la Rosa-Ibarra. 2006. Watermelon response to plastic mulch and row covers. Eur. J. Hort. Sci. 71:262-266.

Jabro, J.D., W.B. Stevens, W.M. Iversen, and R.G. Evans. 2011. Bulk density, water content, and hydraulic properties of a sandy loam soil following conventional or strip tillage. Appl. Eng. Agr. 27:765-768.

Kyrikou, I. and D. Briassoulis. 2007. Biodegradation of agricultural plastic films: A critical review. J. Polymers Environ. 15:125-150.

Lawson, A., A.M. Fortuna, C. Cogger, A. Bary, and T. Stubbs. 2013. Nitrogen contribution of rye-hairy vetch cover crop mixtures to organically grown sweet corn. Renew. Agr. Food Syst. 28:59-69.

Lewis, M. 2015. Advancing ecologicalbased management options for Acalymma vittatum, a key pest of cucurbits. MS Thesis, Pennsylvania State Univ., University Park.

Mischler, R., S.W. Duiker, W.S. Curran, and D. Wilson. 2010. Hairy vetch management for no-till organic corn production. Agron. J. 102:355-362.

Rojas, E.S., M.L. Gleason, J.C. Batzer, and M. Duffy. 2011. Feasibility of delaying removal of rowcovers to suppress bacterial wilt of muskmelon (Cucumis melo). Plant Dis. 95:729-734.

Ruidisch, M., J. Kettering, S. Arnhold, and B. Huwe. 2013. Modeling water flow in a plastic mulched ridge cultivation system on hillslopes affected by South Korean summer monsoon. Agr. Water Mgt. 116:204-217.

Pedersen, A.B. and L.D. Godfrey. 2011. Evaluation of cucurbitacin-based gustatory stimulant to facilitate cucumber beetle (Coleoptera: Chrysomelidae) management with foliar insecticides in melons. J. Econ. Entomol. 104:1294-1300.

Ruiz-Machuca, L.M., L. Ibarra-Jimenez, L.A. Valdez-Aguilar, V. Robledo-Torres, A. Benavides-Mendoza, and M. CabreraDe La Fuente. 2015. Cultivation of potato-use of plastic mulch and rowcovers on soil temperature, growth, nutrient status, and yield. Acta Agriculturae Scandinavica Section B Soil Plant Sci. 65:30-35.

Sánchez, E., T. Elkner, W.J. Lamont, K. Demchak, M.D. Orzolek, B.K. Gugino, J.M. Halbrendt, S.J. Fleischer, L. LaBorde, K. Hoffman, and G.J. San Julian. 2013. Commercial vegetable production recommendations: Pennsylvania. Penn State Ext. Publ. AGRS-028.

Sánchez, E.S., E. Hernández, M.L. Gleason, J.C. Batzer, M.A. Williams, T. Coolong, and R. Bessin. 2015. Optimizing rowcover deployment for managing bacterial wilt and using compost for organic muskmelon production. HortTechnology 25:762-768.
Schipanski, M.E., M. Barbercheck, M.R. Douglas, D.M. Finney, K. Haider, J.P. Kaye, A.R. Kemanian, D.A. Mortensen, M.R. Ryan, J. Tooker, and C. White. 2014. A framework for evaluating ecosystem services provided by cover crops in agroecosystems. Agr. Syst. 125:12-22.

Soltani, N., J.L. Anderson, and A.R. Hamson. 1995. Growth analysis of watermelon plants grown with mulches and rowcovers. J. Amer. Soc. Hort. Sci. 120:1001-1009.

Sullivan, D.M. and N.D. Andrews. 2012. Estimating plant-available nitrogen release from cover crops. 28 May 2013. $<$ http://ir.library.oregonstate.edu/ xmlui/bitstream/handle/1957/34720/ pnw636.pdf>.

Tillman, J., A. Nair, M. Gleason, and J. Batzer. 2015. Evaluating strip tillage and rowcover use in organic and conventional muskmelon production. HortTechnology 25:487-495.

Wang, G.Y. and M. Ngouajio. 2008. Integration of cover crop, conservation tillage, and low herbicide rate for machineharvested pickling cucumbers. HortScience 43:1770-1774.

Yaffa, S., U.M. Sainju, B.P. Singh, and K.C. Reddy. 2000. Fresh market tomato yield and soil nitrogen as affected by tillage, cover cropping, and nitrogen fertilization. HortScience 35:1258-1262.

Yaghi, T., A. Arslan, and F. Naoum. 2013. Cucumber (Cucumis sativus, L.) water use efficiency (WUE) under plastic mulch and drip irrigation. Agr. Water Mgt. 128:149-157.

Zhou, X., M. Al-Kaisi, and M.J. Helmers. 2009. Cost effectiveness of conservation practices in controlling water erosion in Iowa. Soil Tillage Res. 106:71-78.

Zotarelli, L., M.D. Dukes, J.M. Scholberg, T. Hanselman, K. Le Femminella, and R. Munoz-Carpena. 2008. Nitrogen and water use efficiency of zucchini squash for a plastic mulch bed system on a sandy soil. Sci. Hort. 116:8-16. 